Original Research

\title{
Correlation Between Emotional Peer Support and Cyberbullying Behaviour in Senior High School Students
}

\section{Emi Wuri Wuryanningsih, Enggal Hadi Kurniyawan, and Emila Cahya Aisyah}

Faculty of Nursing, Universitas Jember, East Java, Indonesia

\section{ABSTRACT}

Introduction: The biggest users of the internet and social media are teenagers. This has an impact on the tendency for harassment behavior known as cyberbullying. This harassment is quite serious because it is massive; it can happen at any time and anywhere. This harassment generally comes from the victim's peers. This research aimed to analyze the correlation between peer emotional support and the cyber-bullying behavior among the students in senior high school.

Methods: This research used a cross-sectional study design. The sample size of this study was 246 students in senior high school from the academic year 20182019 collected through purposive sampling. The instrument of this research was emotional support from their peers and cyberbullying behavior. The bivariate analysis used was the Spearman test $(\alpha<0.05 ; \mathrm{CI}=95 \%)$.

Results: There is a significant correlation between emotional peer support and cyberbullying behavior among the students in senior high school.

Conclusion: Community health nurses should improve the emotional peer support among the students in order to promote the prevention of cyberbullying behavior.

\section{ARTICLE HISTORY}

Received: December 6, 2019

Accepted: January 14, 2020

\section{KEYWORDS}

Cyberbullying; peer emotional support; senior high school student

\section{CONTACT}

Emi Wuri Wuryanningsih $\triangle$ emi_wuri.psik@unej.ac.id $\ggg$ Faculty of Nursing, Universitas Jember, East Java, Indonesia

Cite this as: Wuryanningsih, E. W., Kurniyawan, E. H., \& Aisyah, E. C. (2019). Correlation Between Emotional Peer Support and Cyberbullying Behaviour in Senior High School Students. Jurnal Ners, 14(2), 205-209. doi:http://dx.doi.org/10.20473/jn.v14i2.13726

\section{INTRODUCTION}

One of the characteristics of the development of high school-aged adolescents is that they need friends, that they are eager to try everything that is not yet known to them and they have a desire to explore their natural surroundings (Putro, 2017). This has an impact on their use of the internet and social media, which is high in the adolescent age group. Data from the Indonesian Internet Service Providers Association (2018) shows that the number of internet users in Indonesia has now reached 88.1 million. Most users are teenagers, especially those in high school, reaching $64.7 \%$. Teenagers use social media to interact with their friendship groups. The results related to conventional harassment behavior tends to shift towards cyberbullying. A survey was conducted with 259 participants as the sample $(202$ female), with all of the respondents aged 19-25 years of. In this survey, 58,1\% had experienced some form of cyberviolence (Ham \& Livazovic, 2019). Cyberbullying perpetration indicates the "repeated violation, harassment and ridicule of others online, or using mobilephones or even other electronic devices" (Patchin and Hinduja, 2012). Cyberbullying is a mischievous behavior that is usually done by individuals or groups intentionally and repetitively on purpose to harm others using computers, phones, and other electronic devices. Additionally, this behavior has so far been considered safe because adults do not recognize when the behavior occurs. This is as it is not easy to monitor activity related to the internet (Sari, 2016). Using technology, people can do things that may bring either good or harm to both themselves and others (Utami, 2014). The user of the internet is not limited because all circles can access it quickly and they are free to do anything (Bauman, Toomey, \& Walker, 2013). 
In Indonesia, there are no age restrictions for smartphone users. There is a vulnerability associated with the negative impact of smartphone use in adolescents, both emotionally and socially. Based on the results of the study, it shows that $21 \%$ report regular cyber-victimization with a distinct emotional disturbance (31,3\%), anger (20,8\%), helplessness $(13,1 \%)$ and sorrow $(20,5 \%)$ (Ham \& Livazovic, 2019). The victims also feel insecure in any situation and they often experience despair due to the oppression in cyberspace (Vaillancourt, Faris, \& Mishna, 2017). The victims feel afraid and uncomfortable with and in their environment, and the victims furthermore feel insecure and threatened in terms of their safety (Hidajat, Adam, Danaparamita, \& Suhendrik, 2015). Cyberbullying behavior that occurs over a long period of time can have an impact on the victim's psychology, such as a loss of self-confidence, increased anxiety and decreased performance (Rifauddin, 2016).

Cyberbullying behavior uses more forms of verbal communication through writing such as what is experienced on the internet and through social media (Maya, 2015). Willard (2007) indicated a taxonomy of the different types of cyberbullying: 1) flaming (i.e. an online fight), 2) harassment (i.e. repetitive, offensive messages), 3) outing and trickery (i.e. soliciting personal information from someone and then electronically sharing that information without the individual's consent), 4) exclusion (i.e., blocking an individual), 5) impersonation (i.e. posing as the victim), 6) cyberstalking (i.e. sending repetitive threats) and 7) sexting (i.e. distributing pictures of another individual without that person's consent). Cyberbullying behavior is usually done freely on the internet. Moreover, bullies can sometimes be falsely known; their hidden identity allows them to do anything without fear (Narpaduhita \& Suminar, 2014).

Cyberbullying perpetrators among teenagers generally comes from among their friends. Teenagers will behave in order to be accepted by their group of friends even if this behaviour is not in accordance with their wishes. Social support, especially peer emotional support, plays a vital role in preventing cyberbullying behavior. Peer emotional support will build empathy when dealing with the adverse behavioral problems that occur in adolescents (Steffgen, König, Pfetsch, \& Melzer, 2011).Teens receive more emotional support from their peers than from their parents. This may come from the interdependence between them and their peers in terms of giving and receiving support and motivation, which they usually like to do as part of an exchange (Lakon, Wang, Butts, Jose, \& Hipp, 2017; Keliat, 2016). Our study aims to analyze the relationship between peer emotional support and cyberbullying behavior in high school-aged adolescents.
Table 1. Distribution of the Respondents by sex, class, the occupation of their parents, the parents' education, height, and student weight referring to the Senior High School Students, Jember $(n=246)$

\begin{tabular}{lcc}
\hline Characteristics of the respondents & n & $\mathbf{\%}$ \\
\hline Gender & & \\
Men & 62 & 25,2 \\
Women & 184 & 74,8 \\
Class & & \\
X & 125 & 50,8 \\
XI & 121 & 49,2 \\
Parents' job & & \\
Not working & 6 & 2,4 \\
Government employees & 52 & 21,1 \\
Private employees & 73 & 29,7 \\
Entrepreneurship & 63 & 25,7 \\
Etc (farmer, laborer) & 52 & 21,1 \\
Parents' education & & \\
Elementary school & 4 & 1,6 \\
Junior High School & 15 & 6,1 \\
Senior High School & 159 & 64,6 \\
College & 68 & 27,6 \\
Height & & \\
140-150 cm & 37 & 15,0 \\
151-160 cm & 117 & 47,6 \\
161-170 cm & 67 & 27,2 \\
171-180 cm & 25 & 10,2 \\
Body Mass Index (BMI) & & \\
Less weight & 90 & 36,6 \\
Normal weight & 112 & 45,5 \\
Overweight & 41 & 16,7 \\
Obesity & 3 & 1,2 \\
\hline
\end{tabular}

\section{MATERIALS AND METHODS}

This research used an analytical observation design with a cross-sectional approach. This research was conducted in a senior high school in the district of Jember. The population included students from the 10th and 11th grades, totaling 635 students in the 2018-2019 academic year. Based on the Slovin Formula $(d=5 \%)$, the sample size of this study was 246 students via a proportionate stratified random sampling technique. The data was collected between February and March 2019. The instrument of this research was peer emotional support (12 item questions about empathy, caring, concern, positive regard, and encouragement focused towards the person; $\alpha$-Cronbach score $=0,849$ ) and cyberbullying behavior (10 item questions about the identification of the perpretator, victims, both, or none of them regarding cyberbullying; $\alpha$-Cronbach score $=0,849$ ). The data collection was conducted after getting a permit from the school. The students were gathered after informed consent was given and through the students filling in the provided questionnaires. After all of the data was collected, bivariate analysis was performed using the Spearman test $\quad(\alpha<0.05$; $\mathrm{CI}=95 \%$ ). This study was approved by the Health Research Ethics Commission of the Faculty of Dentistry, University of Jember No.334/UN25.8/KEPK/DL/2019.. 
Table 2. Frequency distribution of the respondents' characteristics with the category of cyberbullying in Senior High School Students, Jember $(\mathrm{n}=246)$

\begin{tabular}{|c|c|c|c|c|c|}
\hline \multirow{2}{*}{$\begin{array}{l}\text { Characteristics of the } \\
\text { respondents }\end{array}$} & \multicolumn{4}{|c|}{ Cyberbullying Category } & \multirow{2}{*}{$\begin{array}{l}\text { Total } \\
\text { n (\%) }\end{array}$} \\
\hline & $\begin{array}{c}\text { Perpretator } \\
\text { n (\%) }\end{array}$ & $\begin{array}{l}\text { Victim } \\
\text { n (\%) }\end{array}$ & $\begin{array}{l}\text { Both } \\
\text { n (\%) }\end{array}$ & $\begin{array}{c}\text { Not doing } \\
\text { n (\%) }\end{array}$ & \\
\hline \multicolumn{6}{|l|}{ Gender } \\
\hline Men & $9(14,6)$ & $5(8,0)$ & $5(8,0)$ & $43(69,4)$ & $62(25,2)$ \\
\hline Women & $16(8.7)$ & $28(15,2)$ & $25(13,6)$ & $115(62,5)$ & $184(74,8)$ \\
\hline \multicolumn{6}{|l|}{ Class } \\
\hline$X$ & $11(8,8)$ & $10(8)$ & $14(11,2)$ & $90(72)$ & $125(50,8)$ \\
\hline XI & $14(11,6)$ & 23 (19) & $16(13,2)$ & $68(56,2)$ & $121(49,2)$ \\
\hline \multicolumn{6}{|l|}{ Parents' job } \\
\hline Not working & $1(16,7)$ & $2(33,3)$ & $0(0)$ & $3(50)$ & $6(2,4)$ \\
\hline Government employees & $7(13,5)$ & $8(15,4)$ & $6(11,5)$ & $31(59,6)$ & $52(21,1)$ \\
\hline Private employees & $6(8,2)$ & $9(12,3)$ & $12(16,5)$ & $46(63)$ & $73(29,7)$ \\
\hline Entrepreneurship & $4(6,3)$ & $7(11,1)$ & $8(12,7)$ & $44(69,8)$ & $63(25,7)$ \\
\hline Etc (farmer, laborer) & $7(13,5)$ & $7(13,5)$ & $4(7,7)$ & $34(65,4)$ & $52(21,1)$ \\
\hline \multicolumn{6}{|l|}{ Parents education } \\
\hline Elementary School & $0(0)$ & $1(25)$ & $0(0)$ & $3(75)$ & $4(1,6)$ \\
\hline Junior High School & $3(20)$ & $3(20)$ & $1(6,7)$ & $8(53,3)$ & $15(6,1)$ \\
\hline Senior High School & $16(10,1)$ & $20(12,6)$ & $22(13,8)$ & $101(63,5)$ & $159(64,6)$ \\
\hline College & $6(8,8)$ & $9(13,2)$ & $7(10,3)$ & $46(67,6)$ & $68(27,7)$ \\
\hline \multicolumn{6}{|l|}{ Height } \\
\hline $140-150 \mathrm{~cm}$ & $5(13,5)$ & $6(16,2)$ & $2(5,4)$ & $24(64,9)$ & $37(15)$ \\
\hline $151-160 \mathrm{~cm}$ & $10(8,5)$ & $17(14,5)$ & $16(13,7)$ & $74(63,2)$ & $117(47,6)$ \\
\hline $161-170 \mathrm{~cm}$ & $7(10,5)$ & $7(10,5)$ & $8(11,9)$ & $45(67,1)$ & $67(27,2)$ \\
\hline $171-180 \mathrm{~cm}$ & $3(12)$ & $3(12)$ & $4(16)$ & $15(60)$ & $25(10,2)$ \\
\hline \multicolumn{6}{|l|}{ Body Mass Index (BMI) } \\
\hline Less weight & $7(7,8)$ & $6(6,7)$ & $5(5,5)$ & $72(80)$ & $90(36,6)$ \\
\hline Normal weight & $13(11,6)$ & $10(8,9)$ & $19(17)$ & $70(62,5)$ & $112(45,5)$ \\
\hline Overweight & $5(12,2)$ & $16(39)$ & $5(12,2)$ & $15(36,6)$ & $41(16,7)$ \\
\hline Obecity & $0(0)$ & $1(33,3)$ & $1(33,3)$ & $1(33,4)$ & $3(1,2)$ \\
\hline
\end{tabular}

\section{RESULTS}

Several respondent characteristics were used in the present study including gender, parental occupation, the parent's education and height. Based on Table 1, the frequency distribution of gender obtained from the 246 respondents yielded that the female respondents outnumbered the male respondents with a total of $184(74.8 \%)$. The score for the most common parental occupation was that of a private worker, with a total of 73 students (29.7\%). The second most common occupations were entrepreneurs, civil workers and others. The least common occupation was unemployment. Furthermore, the parental education indicator, which had the most common distribution, was that of senior high school. This is as shown in the response from 159 students (64.6\%). Based on the distribution of height obtained from 246 respondents, most students (as many as 117 students) were 151 to $160 \mathrm{~cm}$ tall. The least common distribution was that from only 25 students at 171 to $180 \mathrm{~cm}$ tall $(10.2 \%)$.

In Table 2, it can be observed that out of the 246 respondents, the male respondents were most often the bullies (as many as 9 students; $14.6 \%$ ). The table also informs us that the most common parental occupation was that of a private worker; $6(8.2 \%)$ were bullies, $9(12.3 \%)$ were victims and $12(16.5 \%)$ were bullies and victims referring back to this. It was also found that cyberbullying incidents occur very little occur for the respondents whose parents did not go to school or who had graduated only from elementary education; none $(0 \%)$ of these respondents were either bullies or bullies and the victims of bullying. Only 1 (25\%) respondent was identified as a victim.

Table 3, on the other hand, explains that the students who became the research respondents preferred receiving emotional support from their peers (195 students or 79.3\%). High peer emotional support means that the students genuinely care about their peers in terms of empathy, caring, concern, positive regard and encouragement. Emotional support is usually characterized by the perception of trust in relation to others (Shensa, Sidani, Escobar-Viera, et al., 2020). Related to this, the indicator of peer emotional support, which was considered to be the most influential, was encouragement toward the person. This is because most of the respondents marked this indicator higher than the other indicators. It was known that from the 246 respondents, most of them (158 64.2\%- respondents) did not become either bullies or victims. The rest of them $(35.8 \%)$ were bullies, victims or both. Finally, the Spearman test resulted in the relationship between the variable of peer emotional support and the variable of cyberbullying behavior as being determined to have a $p$-value of 0.001 . The correlation value was -0.228 . In other words, the correlation of the two variables was classified as low. The negative correlation implies 
that the more that cyberbullying behavior is done, the lower the emotional support from their peers. The less the cyberbullying behavior is done, the higher the emotional support given by their peers.

\section{DISCUSSION}

As found in the present study focused on 246 respondents, the number of students who were both a bully and a victim of cyberbullying was quite considerable. Cyberbullying is commonly done because of the dislike of a person which cannot be directly expressed or uttered in real life. Therefore, social media and online platforms are preferred (Budiarti, 2016). Teenagers who are active users of social media are more prone to cyberbullying behavior as it opens up chances for them to become either bullies or victims of cyberbullying (Mesch, 2009).

A previous study conducted by Febrianti \& Hartana (2014) obtained the result that females are more involved in cyberbullying than males. The findings of the study do not conform to the findings of the present study where more male students are involved in cyberbullying. Male students usually belong to a particular group who like to do bad things to other students outside of the group. Cyberbullying usually happens to people or victims who have a different appearance. For example, if they are smaller in body size or if they seem to weigh more (overweight) than others (Rahayu, 2012). Teenagers with a distinctly bigger or thinner body than their peers tend to be less accepted among their friends, compared to those with an (considered) average body size (Kustanti, 2015).

Emotional support is very crucial because the victims of cyberbullying need to feel comfortable and loved by others, especially their friends (Sundari, 2015). Several factors influence the high and low emotional support given by peers to the teens that are the receivers of the support and the support provider themselves. Emotional support can be in the form of expressions of empathy such as listening, being open, trusting, understanding, compassion, and attention being given. The receiver of the support can be influenced if the receiver of the support does not like to socialize, if they do not get along with others, if they are not motivated to help others and if they not want others to know that she or he needs help. The second factor can be influential because teenagers are not likely to support their friends emotionally if they seem to have nothing (no resource) to help others with, if they struggling with their own depression and if they are not sensitive to their surroundings, thus making them unaware of their friend's emotions (Pragwati, 2014). The ability of the students to get emotional support can help them to overcome the problems that are being faced so then the teens are not immersed in the sadness that is being experienced (Ristianti, 2008).

It is implied in the findings of the present study that there is a correlation between peer emotional
Table 3. Analysis of the Relationships Between Peer Emotional Support and Cyberbullying Behavior in Senior High School Students in Jember

\begin{tabular}{lcc}
\hline \multicolumn{1}{c}{ Variable } & n (\%) & Correlation \\
\hline Peer Emotional Support & & \\
High Peer Emotional & $44(17,9)$ & \\
$\begin{array}{l}\text { Support }(\mathrm{x} \geq 38) \\
\text { Medium Peer Emotional }\end{array}$ & $195(79,3)$ & \\
$\quad$ Support $(22 \leq \mathrm{x}<38)$ & & \\
Low Peer Emotional & $7(2,8)$ & \\
$\quad$ Support $(\mathrm{x}<22)$ & & $r=-0,228$ \\
Cyberbullying Behavior & & $p=0,001$ \\
Categories & & \\
$\quad \begin{array}{l}\text { Perpretator } \\
\text { Victim }\end{array}$ & $25(10,2)$ & \\
$\quad$ Both (perpretator and & $33(13,4)$ & \\
victim) & $30(12,2)$ & \\
$\quad$ Not doing (neither & $158(64,2)$ & \\
perpretator nor victim) & & \\
\hline
\end{tabular}

support and the cyberbullying behavior of teenagers. It was known that the more that cyberbullying behavior is done, the less peer emotional support is being given. This is because the worse the interactions are among their peers, the more this can lead to cyberbullying behavior. Groups of teenagers have a relationship with the cyberbullying behavior of other teenagers. Worse interactions among their peers may trigger cyberbullying (Hinduja \& Patchin, n.d.). Moreover, their peers can play a role in the media related to informing individuals of the social norms or agreements that are allowed to be done by teens. Therefore, teenagers are prone to being involved in cyberbullying because they believe that their negative behavior is confirmed and supported by their friends. In other words, their peers are an essential element in how teenagers behave (Budiarti, 2016). Researchers argue that cyberbullying behavior is a form of negative behavior that results from a lack of peer emotional support. Excellent emotional support will make someone avoid negative behaviors such as cyberbullying.

\section{CONCLUSION}

According to the findings of the study and the discussion in the previous section, it can be concluded that there is a relationship between peer emotional support and cyberbullying behavior.The results imply that the more cyberbullying there is, the lesser peer emotional support has been given.

Prospective studies can focus more on cyberbullying by taking into account other factors in addition to peer emotional support such as the parent's role and the attitude of the groups of their peers towards cyberbullying. Both teachers and parents are expected to play an active role in overseeing the student's activities when they are interacting via the internet. They should also provide good parenting for the students. 


\section{REFERENCES}

Bauman, S., Toomey, R. B., \& Walker, J. L. (2013). Associations among bullying, cyberbullying, and suicide in high school students. Journal of Adolescence, $36(2)$, https://doi.org/10.1016/j.adolescence.2012.12.0 01

Budiarti, A. I. (2016). Pengaruh Interaksi Dalam Peer Group Terhadap Perilaku Cyberbullying Siswa. Jurnal Pemikiran Sosiologi, 3(1), https://doi.org/10.22146/jps.v3i1.23522

Febrianti, R., \& Hartana, G. T. (2014). Cyberbullying Pada Mahasiswa Universitas Indonesia. Skripsi. Jakarta: Fakultas Psikologi Universitas Indonesia.

Hidajat, M., Adam, A. R., Danaparamita, M., \& Suhendrik, S. (2015). Dampak Media Sosial dalam Cyber Bullying. ComTech: Computer, Mathematics and Engineering Applications, 6(1), https://doi.org/10.21512/comtech.v6i1.2289

Hinduja, S., \& Patchin, J. W. (n.d.). Identification, Prevention, and Response. Cyberbullying Research Center.

Keliat, B. (2016). Prinsip dan Praktik Keperawatan Kesehatan Jiwa Stuart, Edisi Indonesia Pertama. Singapura: Elsevier Ltd.

Kustanti, E. R. (2015). Gambaran Bullying Pada Pelajar Di Kota Semarang. Jurnal Psikologi Undip14(1),

https://doi.org/10.14710/jpu.14.1.29-39

Lakon, C. M., Wang, C., Butts, C. T., Jose, R., \& Hipp, J. R. (2017). Cascades of emotional support in friendship networks and adolescent smoking. PLoS ONE, 12(6), https://doi.org/10.1371/journal.pone.0180204

Livazovic, G \& Ham, E. (2019). Cyberbullying and emotional distress in adolescents: the importance of family, peers and school. Heliyon 5: 1-9 https://doi.org/10.1016/j.heliyon.2019.e01992

Mesch, G. S. (2009). Parental mediation, online activities, and cyberbullying. Cyberpsychology and Behavior, https://doi.org/10.1089/cpb.2009.0068

Narpaduhita \& Suminar. (2014). Perbedaan Perilaku Cyberbullying Ditinjau Dari Persepsi Siswa Terhadap Iklim Sekolah Di SMK Negeri 8 Surabaya. Jurnal Psikologi Klinis Dan Kesehatan Mental, 3(3),

Nirwana Sari, R. (2016). Kecerdasan Emosi, Anonimitas dan Cyberbullying (Bully Dunia Maya). Persona:Jurnal Psikologi Indonesia, 5(01), https://doi.org/10.30996/persona.v5i01.741

Patchin, J.W., \& Hinduja, S., (2012). Cyberbullying
Prevention and Response: Expert Perspectives. Routledge, New York

Pragwati, P. Y. M. A. (2014). Hubungan Antara Tingkat Dukungan Sosial Teman Sebaya degan Jenis Mekanisme Koping Terhadap Stres pada Remaja di SMAN 8 Malang.

Putro, K.Z. (2017). Memahami Ciri dan Tugas Perkembangan Masa Remaja.APLIKASIA: Jurnal Aplikasi Ilmu-ilmu Agama. Vol. 17(1): 25-32 ONLINE: ejournal.uin-suka.ac.id/pusat/aplikasia ISSN 1411-8777

Rahayu, F. (2012). Cyberbullying Sebagai Dampak Negatif Penggunaan Teknologi Informasi. Jornal of Information System, 8.

Rifauddin, M. (2016). Fenomena Cyberbullying pada Remaja (Studi Analisis Media Sosial Facebook). Khizanah Al-Hikmah: Jurnal Ilmu Perpustakaan, Informasi, Dan Kearsipan, 4(1),

Ristianti, A. (2008). Hubungan antara dukungan sosial teman sebaya dengan identitas diri pada remaja di SMA Pusaka 1 Jakarta. Jurnal Fakultas Psikologi Universitas Gunadarma, 000, 2-4. Retrieved from http://publication.gunadarma.ac.id/handle/1234 $56789 / 1581$.

Soemartono, H.K. (2018). Survei APJII: Penetrasi Internet di Indonesia Capai 143 Juta Jiwa. Buletin Asosiasi Penyelenggara Jasa Internet Indonesia,

Steffgen, G., König, A., Pfetsch, J., \& Melzer, A. (2011). Are cyberbullies less empathic? Adolescents' cyberbullying behavior and empathic responsiveness. Cyberpsychology, Behavior, and Social Networking, 14(11), 643-648. https://doi.org/10.1089/cyber.2010.0445

Sundari, L. (2015). Hubungan Antara Dukungan Emosional Teman Sebaya dengan Motivasi Berprestasi pada Atlet Hockey di Kabupaten Kendal. Universitas Salatiga.

Utami, Y. C. (2014). Cyberbulliying di Kalangan Remaja (Studi tentang Korban Cyberbullying di Kalangan Remaja di Surabaya). Komunitas, 3(3)

Vaillancourt, T., Faris, R., \& Mishna, F. (2017). Cyberbullying in Children and Youth: Implications for Health and Clinical Practice. Canadian Journal of Psychiatry, 62(6), https://doi.org/10.1177/0706743716684791

Willard, N.E., 2007. Cyberbullying and Cyberthreats: Responding to the challenge of Online Social Aggression, Threats, and Distress. Research Press, Champaign, IL. 